\title{
Bulbous Plants Drimia: "A Thin Line between Poisonous and Healing Compounds" with Biological Activities
}

\author{
Madira Coutlyne Manganyi ${ }^{1, *(D)}$, Gothusaone Simon Tlatsana ${ }^{2}$, Given Thato Mokoroane ${ }^{2}(\mathbb{D}$, Keamogetswe \\ Prudence Senna ${ }^{2}$, John Frederick Mohaswa ${ }^{2}$, Kabo Ntsayagae ${ }^{2}$, Justine Fri ${ }^{2}{ }^{(D)}$ and Collins Njie Ateba ${ }^{3}($ ) \\ 1 Department of Biological and Environmental Sciences, Faculty of Natural Sciences, Walter Sisulu University, \\ PBX1, Mthatha 5117, South Africa \\ 2 Department of Microbiology, Mafikeng Campus, North West University, Mmabatho 2735, South Africa; \\ tlatsanakgosi@gmail.com (G.S.T.); thatogven@gmail.com (G.T.M.); tshego.senna@gmail.com (K.P.S.); \\ johnf6813@gmail.com (J.F.M.); kabokayrock1@gmail.com (K.N.); frijustine2000@gmail.com (J.F.) \\ 3 Food Security and Safety Niche Area, Faculty of Natural and Agricultural Sciences, North-West University, \\ Mmabatho 2735, South Africa; Collins.Ateba@nwu.ac.za \\ * Correspondence: madiramanganyi@gmail.com or mmanganyi@wsu.ac.za
}

Citation: Manganyi, M.C.; Tlatsana, G.S.; Mokoroane, G.T.; Senna, K.P.; Mohaswa, J.F.; Ntsayagae, K.; Fri, J.; Ateba, C.N. Bulbous Plants Drimia: "A Thin Line between Poisonous and Healing Compounds" with Biological Activities. Pharmaceutics 2021, 13, 1385. https://doi.org/10.3390/ pharmaceutics13091385

Academic Editors: Javier Garcia-Pardo, Maria Camilla Bergonzi and Charles M. Heard

Received: 27 May 2021

Accepted: 28 July 2021

Published: 1 September 2021

Publisher's Note: MDPI stays neutral with regard to jurisdictional claims in published maps and institutional affiliations.

Copyright: (c) 2021 by the authors Licensee MDPI, Basel, Switzerland. This article is an open access article distributed under the terms and conditions of the Creative Commons Attribution (CC BY) license (https:// creativecommons.org/licenses/by/ $4.0 /)$.

\begin{abstract}
Drimia (synonym Urginea) plants are bulbous plants belonging to the family Asparagaceae (formerly the family Hyacinthaceae) and are distinctive, powerful medicinal plants. Just some species are indigenous to South Africa and have been traditionally utilized for centuries to cure various diseases and/or ailments. They have been recognized among the most famous and used medicinal plants in South Africa. Traditionally, the plants are used for various illnesses such as dropsy, respiratory disease, bone and joint complications, skin disorders, epilepsy and cancer. A number of studies have reported biological properties such as antiviral, antibacterial, antioxidant and anti-inflammatory, immunomodulatory, and anticancer activities. Their bulbs are a popular treatment for colds, measles, pneumonia, coughs, fever and headaches. However, some plant species are regarded as one of the six most common poisonous plants in Southern Africa that are toxic to livestock and humans. Due to the therapeutic effects of the Drimia plant bulb, research has focused on the phytochemicals of Drimia species. The principal constituents isolated from this genus are cardiac glycosides. In addition, phenolic compounds, phytosterols and other phytochemical constituents were identified. This study constitutes a critical review of Drimia species' bioactive compounds, toxicology, biological properties and phytochemistry, advocating it as an important source for effective therapeutic medicine. For this purpose, various scientific electronic databases such as ScienceDirect, Scopus, Google Scholar, PubMed and Web of Science were researched and reviewed to conduct this study. Despite well-studied biological investigations, there is limited research on the toxic properties and the toxic compounds of certain Drimia species. Searching from 2017 to 2021, Google Scholar search tools retrieved 462 publications; however, only 3 investigated the toxicity and safety aspects of Drimia. The aim was to identify the current scientific research gap on Drimia species, hence highlighting a thin line between poisonous and healing compounds, dotted across numerous publications, in this review paper.
\end{abstract}

Keywords: Drimia; Urginea; poisonous; compounds; toxicity; bulbous plants

\section{Introduction}

Members of the genus Drimia Jacq ex Willd have been utilized since ancient times for various ailments such as dropsy, respiratory ailments, bone and joint complications, skin disorders, epilepsy and cancer. Drimia, also known as Urginea (Hyacinthaceae = Asparagaceae) plant, is a distinctive, highly poisonous, deep-red-color bulb native to the surrounding savanna areas of South Africa [1,2], Africa, Asia and Europe [3]. It is a pear-shaped, onionlike, scaly bulb that may grow up to $30 \mathrm{~cm}$ in diameter and is found below the surface of the soil $[2,3]$. Drimia species are well known in traditional herbal medicine and used for 
the treatment of venereal diseases, such as stomach pain, abdominal pains, backache and hypertension, and as a blood purifier and an abortifacient $[2,4,5]$.

Drimia species and other traditional medicinal plants play an important role in the search for new bioactive compounds. Watt and Breyer-Brandwijk [6] and Hutchings et al. [7] believe that bulbous plants are used to reduce inflammation and possess some antimicrobial activities. In addition, South African traditional healers and herbalists utilize Drimia to treat numerous illnesses such as, but not limited to, diseases or problems related to respiratory dysfunction and problems affecting the bones, joints and skin. According to Watt and Breyer-Brandwijk [6] and van Wyk and Gericke [8], traditional healers use the plant to treat venereal infections, abdominal pain, hypertension and numbness and its water extract to purify blood. The bulb is the most used part of Drimia, as it can be applied in emetics, heart tonics, expectorants, diuretics and ointments [9]. It can increase sex drive in males and help females who are infertile and ease dysmenorrhea [9].

When heated, the bulb scales can treat gout and rheumatic diseases and, when in the form of powder, be used to fight viruses such as influenza and treat chronic diseases such as asthma and bronchitis [10]. Historically, Drimia species bulbs have been utilized for the treatment of respiratory conditions and bone, joint and skin complications. In addition, the people of Asia, Egypt and Europe have used D. maritima to cure diseases and ailments since $1500 \mathrm{BC}$. This Drimia species is famously known for its healing properties, and it is widely distributed in the Mediterranean area, where it has been commercialized [1]. Traditionally, it has been utilized to treat various ailments such as bladder-related problems, headache, infertility and cardiac edema $[11,12]$. The underground parts can be administered orally and externally for ritual washing and cleansing [13]. It also has been used for the treatment of retained placenta and related diseases in cattle [14]. Although this plant is used for most ailments in traditional medicine, traditional practitioners are well informed about the toxic nature of the plant.

A number of studies have been conducted on this plant, showing several antiviral, antibacterial, antioxidant and anti-inflammatory biological activities $[1,15,16]$. Phytochemical screening of Drimia resulted in the isolation of several different bufadienolides such as gamabufotalin-3-O-a-Lrhamnopyranoside, $12 \beta$-hydroxyscillirosidin and arenobufagin-3$O$-a-L-rhamnopyranoside [17]. In another study, fresh bulbs of $D$. sanguinea also yielded other secondary metabolites such as salicylic acid, scillaren A, phloroglucinol, phlorin, 3-hydroxy-4-methylbenzoic acid and 5a-4,5-dihydroscillaren A [18] with tremendous beneficial properties. However, there is a thin line between the poisonous and healing compounds produced by Drimia species. Therefore, in the current review, we conduct an in-depth investigation into the bioactive compounds, toxicology, biological properties and phytochemistry of Drimia, concluding on the utilization of such effective therapeutic compounds in drug development. In the same way, studies have isolated bioactive compounds such as phenolic compounds, cardiac glycosides and phytosterol from various Drimia species for their medicinal properties [1].

\section{Methodology Framework}

The current review was carried out by searching, screening and selecting research studies and/or papers from five electronic databases, including ScienceDirect, Scopus, Google Scholar, PubMed and Web of Science. Searches were conducted from September 2020 to May 2021. Keywords ("Drimia", "Urginea", "Poisonous", "Compounds", "Toxicity", "Bulbous plants") were utilized for article selection and screening of abstracts prior to reviewing full publications. Studies focusing on traditional uses, biological properties, in vitro studies and animal and human studies on the genera Drimia and Urginea were included. Because Drimia is a synonym for Urginea, they are used interchangeably throughout this review.

\section{Botanical Characteristics and Geographical Distribution of Drimia}

Drimia is classified as part of the family Asparagaceae (formerly the family $\mathrm{Hy}-$ acinthaceae). Hyacinthaceae is grouped into 1000 species, with 35 genera currently recognized. Furthermore, the genus Drimia belongs to the subfamily Scilloideae, famously 
known for their bulbous plants. In addition, Drimia consists of nearly 100 species. There is an ongoing debate about the classification of the genera Drimia. The current consensus from taxonomic research indicates that Urginea is a synonym for Drimia species. In the Greek language, "Drimia" translates to drimus, meaning "acrid" or "pungent". Drimia spp. are deciduous, apomorphic, short-lived flowering plants growing from perennial bulbs. Their seeds are usually black and winged $[19,20]$.

According to de Wet [21], Drimia is considered the most important and best-known species among all "slangkop" species. In addition, it is one of the six most common poisonous plants in southern Africa that are toxic to livestock and humans [22]. Drimia can grow in various soil types, including lime, clay and stone soils, as well as alluvial soils near rivers or lakes [1]. It has huge, pear-shaped, onion-like, reddish-brown bulbs that are $30 \mathrm{~cm}$ in diameter, usually dormant, just below the ground surface. The bulb is covered by a variety of thin black or dark-purple scales that have a bitter taste when applied to the tip of the tongue [23-25]. Older bulbs are broken into much smaller bulbs.

The single flowering stem is normally $30 \mathrm{~cm}$ long, but it can grow up to $60 \mathrm{~cm}$ and has several small flowers that appear before the leaves in spring. The flowers appear in early spring (September to November), but flowering can begin as early as mid-July in warmer regions. Indigenous bulbs are noticeably wine red with a woody base plant and flashy roots attached [13]. Various species of the genera Drimia have been sketched: D. maritima [26], D. elata [27] and D. altissima [28]. Raimondo et al. [29] illustrated different parts of Drimia sanguinea under the Red List of South African Plants (SANBI, Pretoria, South Africa) [29].

Drimia spp. are widely distributed throughout Africa [1], Madagascar, the Mediterranean area, southeast Asia and India [20]. Studies have recorded that Drimia spp. grows in various South African provinces such as the North West, Mpumalanga, Free State, Gauteng and Northern Cape. It is also found in countries such as Zimbabwe, Namibia and Botswana. The geographical distribution of $D$. sanguinea is depicted by SANBI, Pretoria, South Africa [29]. The geographical locations of D. intricata [30] and D. sigmoidea are in southern Africa, while other Drimia spp. are widely spread in the Mediterranean, Spain, Sardinia, Corsica, and Egypt [2].

They are widely known for their medicinal properties, as indicated in the oldest written record from 1500 BC. Until now, the genera Drimia have been well investigated for bioactive compounds and commercialized [1].

\section{Traditional Uses of Drimia spp.}

Traditional practitioners use Drimia because of its therapeutic values and toxic properties [1]. The part of the plant that is utilized in most scenarios is the bulb, as it can be used in many forms, such as in powders, decoctions, ointments, poultice, plant juice, infusions and lotions [31,32]. According to Bozorgi et al. [1] and Asong et al. [16], traditional herbalist practitioners prescribe different parts of Drimia to treat, reduce and ease different types of diseases (retained placenta, numbness, dysmenorrhea, venereal infections, rheumatic, abdominal pains, influenza, cancer, headache, respiratory functions, joint and body pain) and conditions such as asthma, low sex drive, bronchitis, gout and infertility. In addition, van Vuuren et al. [13] stated that Drimia spp. can be used to perform ritual cleansing. Recent studies showed that the parts of the plant can either be administered orally or topically, and the prescribed dose of the plant material differs depending on the patient's physical structure and medical conditions, as there is no standardized measurement of prescription. However, traditional herbalists are aware of its nature of toxicity, as described earlier [9]. The brine shrimp lethality assay states that $1 \mathrm{~g}$ of the bulb diluted in $10 \mathrm{~mL}$ of boiled water has no cytotoxic effect. Recently, it was proven that oral administration is the most frequently used method, followed by topical administration of the plant parts of Drimia [33-35]. According to traditional Batswana healers, oral administration is mostly used, as most diseases or conditions start from the inside of the body due to a weakened immune system. Traditional herbalists soak different parts of the plant in water for a few 
days or boil them to extract the bioactive ingredients to be administered orally. They also use it in sprinkling powder, poultice and lotions to be administered topically $[8,31,32,36]$.

Indian squill, known as Urginea, is utilized for pharmaceutical and agricultural purposes in the traditional Indian system (Ayurveda). For centuries, ancient Egyptians introduced Urginea plants for the treatment of edema, emesis and cough. To date, drug development has used these plant species in present-day medicinal expectorant and cold preparations. In addition, Urginea bulb extract was used as a cardiotonic agent by the ancient Romans. Since the 1500s, Urginea (Drimia) plants gained popularity, resulting in the commercialization of their products, such as digitalis glycoside squill as a cardioactive agent in the United States, prior to approval by the German commission [37].

\section{Biological Activities of Drimia spp.}

Cardiovascular effects are the oldest behavior reported among the biological activities of the genus Drimia. Previous in vivo or studies in clinical settings of Drimia species concentrated on this property. D. robusta colonies, both naturally grown and in vitro, demonstrated strong antibacterial and antifungal activity against several pathogens [38], whereby the leaves displayed more strength than the bulb.

\subsection{Antimicrobial Activity}

To date, antibiotic therapy is still regarded as an essential treatment of secondary infections [39], despite the rise in microbial resistance, hence the evolution of chronic diseases [40,41]. A number of studies have reported antimicrobial properties such as antibacterial, antifungal and antiviral properties of the genera Drimia in both in vitro and in vivo models. In addition, reports of the antimicrobial activities of some famous Drimia spp. are well documented; however, the antimicrobial activities of other species are limited. Of the 40 medicinal plants tested against 11 strains of bacteria, $D$. indica was graded as successful against bacterial strains. There was also a record of potent activity of $D$. indica against other bacterial strains, especially Bacillus megaterium and Neisseria gonorrhoeae. D. sanguinea bulbs displayed significant anti-Staphylococcus aureus activity. It was found that D. altissima had no activity against Listeria monocytogenes. No significant antiviral activity from the extract of $D$. maritima was reported. Among the active compounds with antimicrobial properties are the homoisoflavanone compound from D. delagoensis and scillarenin from D. maritima [42]. Baskaran et al. [38] reported that D. robusta showed significant antibacterial activity. Furthermore, the utmost concentration $\left(19.68 \mu \mathrm{g} \mathrm{mg} \mathrm{g}^{-1}\right.$ DW) of proscillaridin A was reported in the roots of ex vitro plants [38].

A study conducted on D. indica displayed antibacterial and antifungal effects. The minimum inhibitory concentrations (MICs) ranged from 8.2 to $10.6 \mathrm{mg}$ for antibacterial effects and 1.36 to $1.38 \mathrm{mg}$ for antifungal effects. Various bioactive compounds such as salicylic acid, quercetin, coumarins, kaempferol, luteolin and apigenin were isolated from D. maritima [43]. Pandey and Gupta [44] extracted the metabolites of Urginea indica (D. indica) from the roots, stems and leaves using polar (aqueous, methanol), dipolar (acetone) and nonpolar (chloroform) solvents. The plant extracts were tested for antimicrobial activity against Bacillus cereus, Staphylococcus aureus, Staphylococcus epidermidis, Escherichia coli, Proteus vulgaris and Pseudomonas aeruginosa and against two fungi, Aspergillus niger and Candida albicans. They reported that root methanol extracts exhibited the highest activity against $B$. cereus, while acetone extracts inhibited P. aeruginosa. Fungi $A$. niger and $C$. albicans were inhibited by root acetone extract. Furthermore, the phytochemical analysis showed major compounds such as alkaloids, tannins, quinones, saponins, flavonoids, glycosides, phytosterols and resins [44].

In another study, the activity of $U$. maritima bulb extract was used to control foodborne pathogens, including Listeria monocytogenes, Escherichia coli, Bacillus subtilis, Bacillus cereus, Klebsiella pneumoniae and Staphylococcus aureus. The bulb extract was also tested against pathogenic Colletotrichum graminicola, Sclerotium rolfsii, Fusarium oxysporum and Penicillium digitatum. The results showed that $U$. maritima bulb extract had the highest antifungal effect 
P. digitatum $\left(\mathrm{EC}_{50}=69.01 \pm 2.29 \mu \mathrm{g} /\right.$ well $)$ and C. graminicola $\left(\mathrm{EC}_{50}=86.89 \pm 1.17 \mu \mathrm{g} / \mathrm{well}\right)$. The highest antibacterial activity was detected against $S$. aureus $(66.81 \pm 1.06 \%)$ and B. subtilis (57.94 $\pm 0.92 \%$ ) [45]. An in vitro propagation study and antibacterial assessments were conducted using E. autumnalis and D. robusta plants. Several bacterial pathogens, including B. subtilis, Micrococcus luteus, Enterococcus faecalis, Klebsiella pneumoniae, S. aureus, $P$. aeruginosa and $E$. coli, were used to determine the antibacterial effectiveness of the plant extracts. D. robusta bulb extract showed excellent antibacterial properties against E. faecalis, S. aureus and M. luteus. Moreover, D. robusta was determined as a noble effective bioresource [46]. Crude extracts of $U$. indica were proven to have good antifungal properties, with high inhibitory effects of $14.06 \pm 0.06 \mathrm{~mm}$ and $13.26 \pm 0.26 \mathrm{~mm}$ against C. albicans and $A$. niger, respectively [47].

It was discovered that chitinase, which is a hydrolytic enzyme that disintegrates glycosidic bonds in chitin, possessed antifungal properties in the Urginea indica (Indian squill) bulbs. The protein was purified, and in vitro results showed inhibitory effects against pathogenic Fusarium oxysporum and Rhizoctonia solani [48]. Matotoka and coworkers [49] conducted a study to determine the effectiveness of herbal concoctions against HIV reversetranscriptase and cyclooxygenase activities. D. elata Jacq. (Sekanama) was one of the plants investigated. The results proved that concoctions made in combination with $D$. elata extracts exhibited the highest HIV reverse-transcriptase effects $\left(\mathrm{IC}_{50}=2.90 \mu \mathrm{g} / \mathrm{mL}\right)$, better than current anti-HIV drugs (lamivudine, zidovudine, lopinavir and ritonavir) [49]. In a previous study, Semenya et al. [50] conducted an ethnobotanical survey on indigenous knowledge about plants used to cure sexually transmitted infections by Bapedi traditional healers. It was determined that the D. elata bulb is used for the treatment of gonorrhea and HIV / AIDS [50]. Several studies have reported various biocompounds such as scillarenin, tannins, cardiac glycosides and bufadienolides isolated from the genera Drimia (Urginea) exhibiting good antiviral activities [50-55].

\subsection{Anti-Inflammatory Activity}

Aqueous extract of $D$. sanguinea has shown a good range of toxic activity against fungi associated with the deterioration of food commodities and herbal drugs with antiaflatoxigenic activity [56]. The bulb of D. sanguinea also possesses an effective antioxidant property [57]. Moreover, a considerable number of antimicrobial compounds have been isolated from extracts of this plant. Several plants have been identified to have anti-inflammatory properties, and most were found to be safe, effective, nontoxic and less toxic anti-inflammatory [58] and antioxidant [59,60]. Current research studies focusing on medicinal plants have been created on the backbone of indigenous knowledge. For example, traditionally, Urginea maritima (D. maritima) has been utilized for the treatment of cardiac disorders and fungal infections and as a diuretic agent. Hence, Kazemi Rad and colleagues [61] investigated the relaxation effect of $U$. maritima on rat tracheal smooth muscles. It was suggested that the incubated tissues compressing $U$. maritima extract showed significantly higher relaxant outcomes compared to the nonincubated tissues. The bronchodilatory effect of the plant extract promotes the beta-2 adrenoceptor and prevents the muscarinic receptor, potassium opening and calcium channels [61]. The anti-inflammatory activity of D. nagarjunae extracts from the leaves and bulbs of the plant using in vitro protein denaturation techniques was investigated further. Nonpolar to polar compounds were extracted by using various solvents, including hexane, chloroform, ethyl acetate, methanol and water. The plant extracts exhibited strong anti-inflammatory activity of $82.97 \% \pm 1.16$ at $100 \mu \mathrm{g} / \mathrm{mL}$ [62]. The cardiac glycoside compound showed a potent acute and chronic inflammatory effect and reduced inflammatory symptoms in vivo and animal models [63]. In an assessment of the anti-inflammatory activity of $U$. indica extracts isolated from aqueous and ethanolic solvents, it was shown that these extracts aid in relieving joint inflammation using various models [64].

\subsection{Antioxidant Activity}

Recently, a study evaluated the effects of $D$. maritima flowers and bulbs (essential oils) using various techniques, including DPPH, ABTS+ and total antioxidant capacity. It 
found that their essential oils possessed excellent antioxidant activity better than Trolox and vitamin E. The nitric oxide chelation scavenging activity of ethanol extracts from bulbs and flowers exhibited $\mathrm{IC}_{50}$ values of 5.05 and $5.12 \mu \mathrm{g} / \mathrm{mL}$, respectively. Analytical GC-MS results showed high levels of eugenol and carvacrol, which account for $41.23 \%$ and $27.29 \%$, respectively. D. maritima essential oils also demonstrated strong antimicrobial activities [64]. In a 2010 study, Mammadov et al. [65] evaluated the antioxidant activities of $U$. maritima extracts produced from leaves and tubers using different solvents such as methanol, benzene, ethanol and acetone. A $\beta$-karotene-linoleic acid system and DPPH assay (free radical scavenging) were utilized to determine the total antioxidant activity of the U. maritima extracts, and according to the results, ethanol extracts showed high antioxidant activity of $72.67 \%$, while the benzine extract activity was $31.12 \%$. In addition, methanol extract demonstrated free radical scavenging activity of 66.89\% [65]. Mahato et al. [66] found methanolic extract of $U$. indica bulbs possessed remarkably antioxidant activity using DPPH assay with an $\mathrm{IC}_{50}$ value of $51.87 \mu \mathrm{g} / \mathrm{mL}$, which was greater than gallic acid with an $\mathrm{IC}_{50}$ value of $39.91 \mu \mathrm{g} / \mathrm{mL}$. In addition, phytochemical screening revealed several biocompounds with alkaloids as the highest quantity, followed by flavonoids, phenols and saponins. The authors recommended U. indica (traditional wild onion) as an alternative for the management of numerous chronic diseases [66].

In a study on the evaluation of the antioxidant and free radical scavenging activity of various Drimia sp. (D. govindappae, D. coromandeliana, D. indica, D. polyantha, D. nagarjunae, D. razii and D. raogibikei) bulb extracts, results demonstrated that $D$. coromandeliana displayed the most antioxidant and free radical scavenging activities [67]. In a recent study, free radical scavenging techniques such as DPPH, superoxide anion, hydroxyl radical and ABTS were utilized to determine the antioxidant activities of $D$. maritima. The ethyl acetate extract demonstrated good scavenging activity and reduced power by employing DPPH and ABTS tests. Furthermore, aqueous extract displayed the highest activity against superoxide anions, hydroxyl radicals and lipid peroxidation [68].

\subsection{Anticancer Activity}

A previous study conducted on the bulbs of South African D. altissima isolated novel bufadienolides and drimianins A-G (1-7). Furthermore, a screening assay utilizing bufadienolide showed anticancer activity against human cancer cell lines in the NCI-60 screen [69,70]. On the other hand, novel flavonoid C-apioglucoside, 6-C-[-apio- $\alpha$ D-furanosyl-(1 $\rightarrow 6)$ - $\beta$-glucopyranosyl]-4', 5, 7-trihydroxyflavone (altissimin) was recently discovered from the chemical characterization of D. altissima. An in vitro bioassay showed antiproliferative potency against HeLa cervical cancer cells [70]. In a study conducted by Bevara et al. [71], the effect of C-glycosyl flavone was tested on human normal epithelial, breast, hepatic and colon cancer cell lines. The results indicate cytotoxicity potency of C-glycosyl flavone with respect to the induction of apoptosis, cell cycle arrest and inhibition of angiogenesis via CDK6 [71].

Proscillaridin A and cardiac glycosides are among the compounds that were isolated from Drimia spp., exhibiting cytotoxic potency and/or antiproliferative activity against human breast carcinoma [72]. In a follow-up study, D. robusta extracts were prepared from whole plants and exhibited anticancer effects against human cell lines such as breast MCF7, melanoma UACC62 and renal TK10 [73]. A recent study on $U$. maritima bulb extract also showed anticancer properties by preventing cell cycle arrest and inducing apoptosis in breast cancer cell lines [74]. In an animal study, $U$. indica methanolic extract revealed anticancer inhibitory potential in Swiss albino mice [75]. A number of researchers have determined that Drimia species have been utilized for a broad spectrum of applications, including ailments, respiratory conditions, bone and skin disorders, joint complications, cancer and epilepsy. An in-depth in vivo and in vitro investigation showed beneficial antibacterial, antiviral, antifungal, anti-inflammatory, antioxidant and insecticidal effects [1], as shown in Table 1. 
Table 1. Biological investigation of Drimia plants.

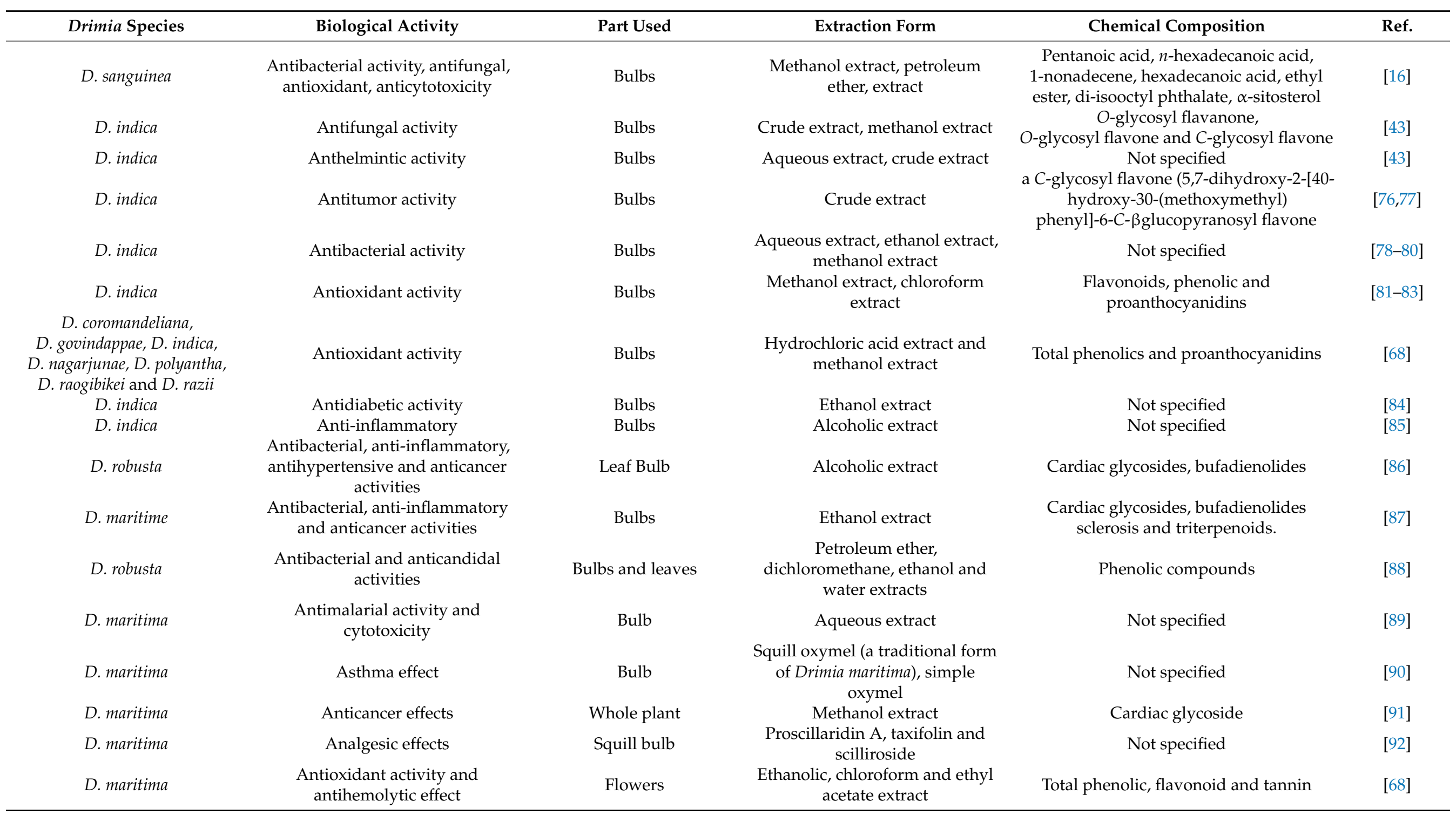


Table 1. Cont.

\begin{tabular}{|c|c|c|c|c|c|}
\hline Drimia Species & Biological Activity & Part Used & Extraction Form & Chemical Composition & Ref. \\
\hline D. robusta & Antibacterial activity & Bulb & Ethanolic extract & $\begin{array}{l}\text { Cardiac glycosides (2-deoxy sugars), } \\
\text { bufadienolides }\end{array}$ & [93] \\
\hline D. maritima & Antioxidant activities & Leaves and tubers. & $\begin{array}{c}\text { Ethanol, methanol, acetone } \\
\text { extracts }\end{array}$ & Phenolic compounds & [68] \\
\hline D. macrocentra and U. riparia & Anticancer activity & Bulbs & Extracts & Bufadienolides, rubellin and riparianin & [94] \\
\hline D. maritima & Acaricidal activity & Leaves and bulbs & $\begin{array}{c}\text { Methanol, ethanol, acetone and } \\
\text { butanol }\end{array}$ & Bufadienolides derivatives & {$[95]$} \\
\hline D. numidica & Antioxidant activity & $\begin{array}{l}\text { Flowers, scales, leaves, } \\
\text { bulbs and roots }\end{array}$ & Methanolic & Bufadienolides and total phenolic content & [96] \\
\hline D. nagarjunae & Anticancer activity & Bulbs and leaves & Ethyl acetate and chloroform & $\begin{array}{l}\text { Acetic acid, (D,L)-malic acid, hexadecanoic } \\
\text { acid, ethyl[4-t-Butyl-2,6-bis(1-methoxy-1- } \\
\text { methylethyl)phenyl]phosphinate, } \\
\text { octadecanoic acid, } \\
\text { 2-hydroxy-1-(hydroxymethyl)ethyl ester }\end{array}$ & {$[62]$} \\
\hline D. maritima & $\begin{array}{l}\text { Decreasing dyspareunia and } \\
\text { increasing sexual satisfaction }\end{array}$ & Squill oil & $\mathrm{N} / \mathrm{A}$ & Flavonoids & [97] \\
\hline D. maritima & Acaricidal activity & Leaves and bulbs & $\begin{array}{c}\text { Methanol, ethanol, acetone and } \\
\text { butanol }\end{array}$ & Bufadienolides & [98] \\
\hline
\end{tabular}




\section{Toxicity of Drimia spp.}

\subsection{Toxicity of Drimia spp. in Animals}

In animals, intoxication may lead to muscular weakness, paralysis and even fatality caused by heart failure [96]. A number of studies have reported cardiac glycoside as a major toxic compound produced by Drimia species [19,99-101]. According to Kellerman et al. [23], livestock ingest the flowers, leaves and sometimes the bulb of this plant as substitutes to green grass, and it was found to be toxic to livestock due to cardiac glycoside extracted from the plant's bulb. Drimia species are considered highly poisonous, especially the bulbs of the plants [102]. Due to the toxic nature, several symptoms following administration have been reported such as diarrhea, indigestion, tremors and cramps. However, toxicity caused by this plant in human beings has not yet been recorded; nonetheless, Louw [103] found that some water-soluble chemicals isolated from this plant's bulbs show toxicity to mankind. The toxicological properties of D. maritima were initially described by Theophrastus. Due to its toxic nature, the plant was placed over doors to clear out venomous insects and animals. Furthermore, in traditional Iranian medicine, D. maritima plant was also utilized as a mice and insect repellent [15]. This plant has been used to poison mice and prevent mice and insects across the world, specifically in Italy. Its popularity spread across the globe from 1920, and D. maritima plant became an effective raticide. Spanish fishermen used the plant bulb as an ichthyotoxic agent. As the word spread, other species within the genera Drimia were investigated for their toxic nature by various nations. South Africa recognized $D$. sanguinea plant as one of the six poisonous plants, and in Tanzania, the plant was known as a very toxic plant [15]. Various tribes across the world utilized the plant to detoxify herbs prior to medicinal care. Detoxification by Indian tribes using $D$. indica included saturating the plant in rainwater, boiling it and cooking it. Herbal concoctions of D. sanguinea bulbs (ratio of 1:10 $(w / v)$ of water) prepared by traditional African healers did not have any toxicity on shrimps.

Iranian traditional healers usually add D. maritima bulb to Vicia ervilia paste and bake it. D. maritima bulb is also mixed with honey or water then boiled for the production of squill vinegar and oxymel [15]. D. sanguinea bulbs have exhibited significant cytotoxic effects. In a study performed on the mouse fibroblast L929 cell line, aqueous plant extract showed a reduction in cell viability at a $0-2.4 \mathrm{mg} / \mathrm{mL}$ dose. However, the number of cells was unchanged. At a $0-1.2 \mathrm{mg} / \mathrm{mL}$ dose, $D$. sanguinea extract was potent against cell cultures of chicken embryonic neurons. This activity resulted in the morphological alteration of chick embryo neurons and necroapoptosis, which was familiarized as the primary mechanism. Researchers rationalize the biological potency as a result of biocompounds such as cardiac glycosides, particularly transvaalin. Certain compounds may prevent the $\mathrm{Na}+/ \mathrm{K}+-$ ATPase pump, subsequently leading to an increase in intracellular calcium. Excess of calcium through the mitochondrial permeability transition pathway may result in necroapoptosis. The salicylate compound produced from $D$. sanguinea might stimulate the process. Hence, damage of the axon, neuroglia and astrocytes may occur as a result of an abundance of intracellular calcium [2].

Various cardiac glycosides have been reported as the main contributors to the toxic nature of Drimia sp. Furthermore, scilliroside, belonging to bufadienolide glycoside, has been shown to be a toxic compound of D. maritima red plants. In an in vivo study, the lethal dose $\left(\mathrm{LD}_{50}\right)$ of scilliroside was 0.7 and $0.43 \mathrm{mg} / \mathrm{kg}$, respectively, for male and female rats. An earlier study showed an $\mathrm{LD}_{50}$ for male rats of $0.8 \mathrm{mg} / \mathrm{kg}$ and $0.52 \mathrm{mg} / \mathrm{kg}$ for female rats [104]. Approximately, at a $100 \mathrm{mg} / \mathrm{kg}$ dose, contraction of muscles was recorded after 1-2 $\mathrm{h}$ and death after $13.2 \mathrm{~h}$. Scilliroside and its aglycon, scillirosidin, have shown increased toxic levels compared to other bufadienolides such as proscillaridin and desacetylscillirosidin. This may be due to the acetoxy group at the C-6 position of scilliroside. The outcomes of various studies have propelled the use of scilliroside as a rodenticide. The results have shown that female rats are more sensitive to scilliroside than their male counterparts; hence, toxicity is reduced due to the testosterone in the male rats. The outcomes also suggest that mice are killed by scilliroside with smaller quantities compared to rats. The lethal 
dose $\left(\mathrm{LD}_{50}\right)$ of proscillaridin (a type of bufadienolide) isolated from Drimia species was $0.25 \mathrm{mg} / \mathrm{kg}$ through oral administration in newborn rats. Moreover, in mature rats, the oral $\mathrm{LD}_{50}$ was 56.2 and $76.5 \mathrm{mg} / \mathrm{kg}$ for male and female rats, respectively, while intravenous (IV) showed an $\mathrm{LD}_{50}$ of 8.7 and $17 \mathrm{mg} / \mathrm{kg}$ for male and female rats, respectively. The significant difference between oral and IV toxicity in infants and mature rats means higher sensitivity of young rats to proscillaridin, which has nothing to do with intestinal absorption varieties. Transvaalin was isolated from $D$. sanguinea plants, which was regarded as a principal toxic bufadienolide compound; however, this was identical to scillaren A. The lethal doses of transvaalin (scillaren A) and proscillaridin through the IV route in cats were reported as $0.156,0.167$ and $0.184 \mathrm{mg} / \mathrm{kg}$, respectively. Scillaren is a derivative cardiac glycoside of Drimia sp., which results in cholestasis in rat liver by impacting the blood flow [104].

Teshome and colleagues [105] studied D. altissima plants to assess the toxicity and palatability of the bulbs by utilizing the rat model obtained from the field. Furthermore, the study aimed to use D. altissima plants as potential rodenticide candidates. Various groups (treatment and control) of rats were administered different concentrations of D. altissima concoctions in a controlled laboratory environment, and the fatality count was documented during the experiment period. The results showed a large number $(80-100 \%)$ of fatalities after administration of the poison bait of D. altissima. In addition to this, the powdered bulb was responsible for $8 \%$, producing $50 \%$ of the fatalities. The researchers concluded that the powdered bulb of $D$. altissima caused fatalities in rat mortality; however, no fatalities were recorded in the control group. Moreover, an in-depth investigation is required to support and expand on the toxicological properties of D. altissima bulb and its active compounds [105]. A study conducted on the toxicity properties of D. maritima prepared in ethanolic extract was used to investigate the fatality rate, sexual conduct and oviposition behavior of vinegar fly, Drosophila melanogaster. The vinegar fly was used as a test model in the laboratory environment. Administration of the treatment was conducted by ingestion of second-stage larvae (L2). Laboratory data indicated that $100 \%$ of fatalities were achieved after 15 days of treatment. In addition, there was a significant reduction in the quantity of eggs laid and larvae quantity of the first-generation-treated and partial nuptial courtship. The results showed the neurotoxic effects of D. maritima ethanolic extract, suggesting the plants produced toxic secondary metabolites [106].

\subsection{Toxicity in Humans}

Tuncok and coworkers [107] reported that Drimia species caused the death of a 55-yearold woman who ingested two bulbs orally due to arthritic pain. Before ingesting this herb, she was diagnosed with Hashimoto's thyroiditis and hypothyroidism, which might have been associated with serious toxicity. Digitalis-like signs of poisoning included vomiting, seizure, severe hyperkalemia, ventricular arrhythmias and atrioventricular block [107]. Squill opiate linctus, which was applied as a cough remedy in two patients, caused toxic effects. Bradycardia and other signs of digitalis intoxication were found in both cases, and toxicity occurred after an overdose of this drug [108]. The major symptoms of 14 patients with $D$. sanguinea poisoning are gastrointestinal, central nervous system and urinary tract problems. Accidental inhalation of a scilliroside-containing substance under the trade name "Silmurine" resulted in certain effects that were not prolonged, such as headache and vomiting. Bulbs and leaves of Drimia species can cause itching and skin inflammation because of their calcium oxalate content [9]. Polat et al. [109] utilized D. maritima bulbs as a topical application for arthralgia, which resulted in nonallergic irritant contact dermatitis in a 52-year-old woman. To determine the toxicology of poisonous plants including Drimia species, more in-depth studies are required using in vitro and in vivo models in both animal and human clinical investigations. Table 2 indicates some toxicity effects Drimia species reported so far in animal models. 
Table 2. Toxicological effects of Drimia species.

\begin{tabular}{|c|c|c|c|c|}
\hline Drimia Species & Toxicity Effects & Model Used & Compounds & Ref. \\
\hline D. indica & Antidiabetic effects, acute toxicity & Rat model & Not specified & [84] \\
\hline D. robusta & Hemolytic activity induces toxicity & In vitro & Saponins, proscillaridin A, & [93] \\
\hline U. maritima & Mortality rate was $10 \mathrm{mg} / \mathrm{mL}$ after $48 \mathrm{~h}$ & Mite & $\begin{array}{c}\text { quercetin, kaempferol and } \\
\text { bufadienolides }\end{array}$ & [65] \\
\hline D. altissima & Rodenticides $80-100 \%$ fatalities & Rat model & Not specified & [105] \\
\hline D. pancration & Repellent activity and contact toxicity & $\begin{array}{c}\text { Stegobium paniceum } \\
\text { beetles }\end{array}$ & Steroidal saponins & [110] \\
\hline $\begin{array}{c}\text { C-glycosyl flavone of } \\
\text { D. indica }\end{array}$ & $\begin{array}{l}\text { No mortality at } 250 \mathrm{mg} / \mathrm{kg} \text { bw; } \\
\text { nonetheless, } 50 \text { and } 100 \% \text { mortality was } \\
\text { detected at } 500 \text { and } \\
1000 \mathrm{mg} / \mathrm{kg} \mathrm{bw}\end{array}$ & Mice & C-glycosyl flavone & [71] \\
\hline D. maritima & $\begin{array}{l}\text { resulted in } 100 \% \text { mortality in larvae and } \\
48 \% \text { mortality in adult beetles. } \mathrm{LC}_{50} \text { and } \\
\mathrm{LC}_{90} \text { values were } 16.6 \text { and } 34.4 \mathrm{~g} / \mathrm{L}, \\
\text { respectively }\end{array}$ & $\begin{array}{l}\text { Larvae and } \\
\text { beetle }\end{array}$ & Not specified & [111] \\
\hline
\end{tabular}

From the Google Scholar search tool, a total of 462 publications were retrieved by using keywords "Urginea" and "Toxicity" from 2017 to 2021 (5 years). Out of these publications, only three were applicable. Furthermore, screening other electronic databases such as ScienceDirect, Scopus, PubMed and Web of Science showed a lower number of publications. The selection process used a combination of keywords such as "Drimia", "Urginea", "Compounds", "Toxicity" and "Safety", and the findings are summarized in Table 3.

Table 3. Results of the Database Search on Urginea, Drimia and toxicity from 2017 to 2021.

\begin{tabular}{cccccc}
\hline Search Tool & Google Scholar & ScienceDirect & Scopus & PubMed & Web of Science \\
\hline Urginea & $462(3)$ & $56(1)$ & $3(0)$ & $8(1)$ & $7(2)$ \\
\hline Drimia & $308(2)$ & $49(1)$ & $6(3)$ & $6(2)$ & $9(3)$ \\
\hline \multicolumn{5}{c}{ Numbers in brackets (applicable publications) } \\
\hline
\end{tabular}

\section{Phytochemicals of Drimia spp.}

Due to the therapeutic effects of $D$. sanguinea bulb, researchers have focused on the phytochemicals of Drimia species, and the leaves and roots have also been examined [1]. The principal constituents isolated from this genus are cardiac glycosides. In addition, in these plants, phenolic compounds, phytosterols and other phytochemical constituents have been identified $[112,113]$. The major phytochemicals that are commonly present in Drimia spp. are alkaloids, tannins, quinones, saponins, flavonoids, glycosides, phytosterols, resins, salicylic acid, quercetin, coumarins, kaempferol, luteolin and apigenin $[43,44]$. In another study, GC-MS analysis was utilized to identify compounds in U. indica crude extract. The results showed 36 compounds were identified, namely 9,12,15-octadecatrienoic acid, stigmasterol, squalene, hypocholesterolemic $n$-hexadecanoic acid, diuretic phytol, pyrogallol $10.40 \%, 9,12$-octadecadienoic acid and octadecanoic acid. In addition, a number of alkaloids, flavonoid glycosides, saponins, proteins and carbohydrates were recognized [52].

\subsection{Cardiac Glycosides}

The positive impact on the function of the heart and blood vessels (cardioactive effect) caused by Drimia species has sparked interest in the identification of compounds since the early 1800s [1]. In 1933, Arthur Stoll was the first person to extract scillaren A (cardiac glycoside) from D. maritima, which was a novel discovery in cardiac therapy [114]. Cardiac glycosides are organic steroidal compounds consisting of C-24 or C-23 and biological properties such as inotropic and chronotropic effects [115]. Furthermore, the cardiac glucoside 
structure is composed of tetracyclic 10, a 13-dimethyl-cyclopentanoperhydrophenanthrene nucleus and its steroidal nucleus, which is known by the cell receptors [116,117].

A comparative study was conducted by El-Seedi et al. [92], whereby 61 Egyptian medicinal plants from 29 families were investigated. The study suggested that cardiac glycoside from $U$. maritima was accountable for the cytotoxic activities [92].

Cardenolides and bufadienolides (Figure 1) are chemical compounds belonging to cardiac glycosides, depending on the lactone ring comprising five or six carbon atoms [118,119]. The sugar moiety of cardenolides and bufadienolides affects pharmacological actions. In this regard, the sugar chain consists of one to three sugars, which are connected to Position 3 of the steroidal core [120]. Morsy [121] reported that flowering plants (angiosperms) are an abundant source of cardiac glycosides. Cardenolides are widely abundant compared to bufadienolides, and there is little possibility to obtain bufadienolide from animals and plants. Proscillaridin A (endogenous bufadienolides) has been obtained from mammalian plasma and other body fluids. However, Drimia plants are rich in bufadienolide.

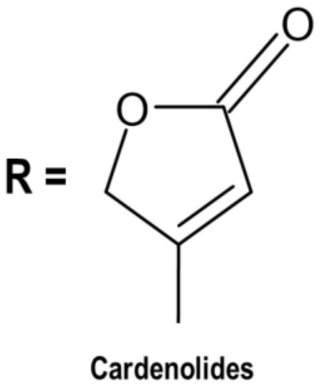

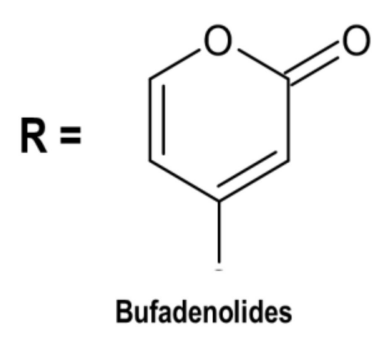

Bufadenolides

Figure 1. Two classes of cardiac glycosides occurring in nature [118].

Follow-up studies were conducted based on the initial isolation of scillaren from D. maritima plant in 1933 [114], and researchers focused on bufadienolide from Drimia plants. Nuclear magnetic resonance spectroscopy (NMRS) for the identification of bufadienolides and high-performance liquid chromatography (HPLC coupled with a detector) were also utilized to identify the compounds in a mixture [121].

Analytical techniques were also used for the detection of major constituents, including proscillaridin A, scillaren A and scillirosiden from different varieties of D. maritima. In addition to bufadienolide compounds, several cardenolides were isolated from methanolic extract of D. fugax, and the structure of new cardenolide was elucidated using highfield NMR spectroscopy. In a recent study, phytochemical investigations showed cardiac glycosides of Indian Drimia exhibited significant antioxidant properties, which serves as an ideal candidate for the isolation of bufadienolides. Bufadienolides, namely scillaren A, were isolated from D. coromandeliana and D. razii [25]. Proscillaridin A (cardiac glycoside) derived from U. maritima exhibited antimicrobial [38] and anticancer properties [73]. Several studies have utilized this compound for the treatment of congestive heart failure and cardiac arrhythmia [38,73,122].

An earlier study used fast atom bombardment mass spectrometry (FAB-MS) and nuclear magnetic resonance (NMR) to detect 10 unknown biocompounds (Compounds 6 , $14,17,19,22-26$ and 32) from the bulbs of $U$. maritima. Compounds 6,14 and 17 belonged to bufadienolides, which lacked sugars; Compound 32 was lignan glycoside, which is unusual in U. maritima; and Compounds 19 and 22-26 were unfamiliar bufadienolide glycosides [123]. Cardiac glycosides are characterized as sugar residue with an unsaturated lactone ring (five or six atoms) and a steroidal residue. These secondary compounds are produced in plants, insects and animals. In the past, plant or animal extracts comprising cardiac glycosides were used for diuretics, emetics, as poison on arrows and darts and for suicide or murder [124]. 


\subsection{Phenolic Compounds}

A number of phytochemical compounds have been isolated and identified from Drimia species, including flavonoids, which are phenolic metabolites [23]. The TLC technique was used to detect the flavonoid compounds from cardiotonic glycosides [125]. Freeform pelargonidin-3-monoglucoside and cyanidin-3-monoglucoside and $\rho$-cumaric acid acylated with caffeic acid were obtained from Spanish D. maritima (red bulbs). Other phenolic compounds were quercetin-3-monoglucoside, taxifolin $4^{\prime}$-glucoside and $C$-glycosyl flavones.

Figure 2 illustrates some chemical structures of phenolic compounds such as taxifolin $\left(\mathrm{C}_{15} \mathrm{H}_{12} \mathrm{O}_{7}\right)$, quercetin-3-monoglucoside $\left(\mathrm{C}_{21} \mathrm{H}_{19} \mathrm{O}_{12}\right)$ and flavonoid C-glycosyl $\left(\mathrm{C}_{22} \mathrm{H}_{22} \mathrm{O}_{11}\right)$ isolated from Drimia spp. A homoisoflavonoid compound was isolated from $D$. delagoensis. Three flavonoid glycosides were identified in $D$. indica bulbs. Caffeic acid from D. maritima, 4-hydroxy-3-methoxybenzoic acid from $D$. delagoensis and phloroglucinol derivatives from $D$. sanguinea were also identified as other phenolic constituents [1]. Langat et al. [70] discovered a new flavonoid called C-apioglucoside, 6 -C-[-apio- $\alpha$-D-furanosyl-( $1 \rightarrow 6)-\beta$ glucopyranosyl] $-4^{\prime}$, 5, 7-trihydroxyflavone, which was isolated from $D$. altissima plants. Moreover, the compound exhibited good antiproliferative potential [70]. Various phytochemicals were isolated and identified from the bulbs of $U$. maritima, and the main findings revealed high concentrations of polyphenols and flavonoids. Furthermore, HPLCESI/TOF-MS analysis detected ferulic acid, vanillic acid and 4-hydroxybenzoic acid as the main phenolic compounds. The biocompounds exhibited some beneficial insecticidal properties and restrictive activity on the acetylcholinesterase enzyme system in the rice weevil Sitophilus oryzae (L.) (Coleoptera: Curculionidae) [45].<smiles>O=C1c2c(O)cc(O)cc2O[C@@H](c2ccc(O)c(O)c2)C1O</smiles>

2a. Taxifolin<smiles>O=c1cc(-c2ccccc2)oc2ccccc12</smiles>

2c. Flavone<smiles>O=c1c2c(oc3cc(O)cc(O)c13)OC1OC(O)C(O)C3=C1C2(O)C=C(O)C3(O)O</smiles>

2b. Quercetin-3-monoglucoside<smiles>O=c1cc(-c2ccc(O)cc2)oc2c(C3O[C@H](CO)[C@@H](O)[C@H](O)[C@H]3O)c(O)cc(O)c12</smiles>

2d. C-glycosides (vitexin)

Figure 2. Chemical structures of phenolic compounds isolated from Drimia spp. [1]. (a). Taxifolin (Type of flavonoid, $\left.\mathrm{C}_{15} \mathrm{H}_{12} \mathrm{O}_{7}\right) ;(\mathbf{b})$. Quercetin-3-monoglucoside $\left(\mathrm{C}_{21} \mathrm{H}_{19} \mathrm{O}_{12}\right)$; (c). Flavone $\left(\mathrm{C}_{15} \mathrm{H}_{10} \mathrm{O}_{2}\right)$ and (d) Vitexin (Type of flavone glycosides, $\mathrm{C}_{21} \mathrm{H}_{20} \mathrm{O}_{10}$ ).

In a follow-up study, various biocompounds such as tannins, phenols and flavonoids were extracted from $U$. indica bulb extracts and identified [66]. A number of secondary compounds were produced from the fresh plant material of red sea squill (U. maritima). The plant extract was prepared with aqueous acetone (90:10, $v / v)$. Reverse-phase HPLC (RP-HPLC) coupled with DAD and MSn detection was used to identify several compounds, including cardiac glycosides, phenolic acids and flavonoids. Dihydroquercetin, which 
is a potent flavonoid, was detected in high concentrations [126]. In the endless pursuit of novel biocompounds, Sultana et al. [127] discovered three unknown flavonoid glycosides, namely 5,4'-dihydroxy-3-O- $\alpha$-L-rhamnopyranosyl-6-C-glucopyranosyl-7-O-(6 ${ }^{\prime \prime}$-paracoumaroyl- $\beta$-D-glucopyranosyl) flavone (2)5,6-dimethyoxy-3' $4^{\prime \prime}$-dioxymethylene-7-O- $\left(6^{\prime \prime}\right.$ $\beta$-D-glucopyranosyl- $\beta$-D-glucopyranosyl) flavanone (1), and 5,4'-dihydroxy-3-O- $\left(2^{\prime \prime \prime \prime \prime}-\beta\right.$ glucopyranosyl- $\alpha$-L-rhamnopyranosyl)-6-C-glucopyranosyl-7-O-(6" ${ }^{\prime \prime}$-para-coumaroyl- $\beta$-Dglucopyranosyl) flavone (3) from $U$. indica bulbs (Indian squill) [127].

\subsection{Phytosterols}

A study showed that beta- and gamma-sitosterol were obtained from $D$. indica bulbs. Furthermore, the leaves, bulbs and roots of different $D$. indica cytotypes were studied, and phytosterols was the dominating sterol, followed by stigmasterol. Campesterol was only obtained from triploides. Stigmasterol was also isolated from D. sanguinea bulbs [1]. The chemical structures of phytosterols, including cholesterol, campesterol and stigmasterol isolated from Drimia spp., are displayed in Figure 3. Phytosterols, $\beta$-sitosterol and stigmasterol were detected in plant parts of $U$. indica. The highest total sterol content was noticeable in the leaf with $23.46 \mathrm{mg} / \mathrm{gdw}$, and the lowest was observed in the bulb with $18.18 \mathrm{mg} / \mathrm{gdw}$ [128]. However, Raj and Kameshwari [55] utilized liquid chromatographymass spectroscopy (LC-MS) and nuclear magnetic resonance (NMR) to determine the biocompounds in $U$. wightii extract. Several secondary compounds, including hexadecanoic acid methyl ester, 1,3,7,11,15-tetramethyl-2-hexadecenol and stigmasterol, were identified and established to possess antioxidant effects [55]. Phytosterols are generally referred to as plant sterols that are similar to cholesterol in structure with distant sidechain configurations. They are triterpenes with a four-ring steroid nucleus, the $3 \beta$-hydroxyl group and, frequently, a 5,6-double bond. In addition, the purpose of phytosterols is to balance the phospholipid bilayers in cell membranes. They have various applications in cosmetics, nutrition and therapeutic purposes. Other critical properties include anticancer properties [129].

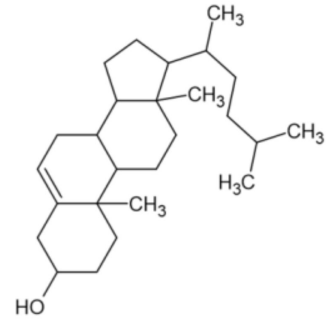

3a. Cholesterol

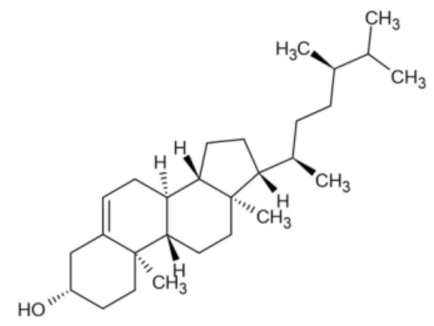

3b. Campesterol<smiles>CCC(/C=C/C(C)[C@]1(C)CC[C@H]2[C@@H]3CC=C4CC(O)CCC4(C)[C@@]3(C)CC[C@]21C)C(C)C</smiles>

3c. Stigmasterol

Figure 3. Chemical structures of phytosterols isolated from Drimia spp. [1]. (a). Cholesterol $\left(\mathrm{C}_{27} \mathrm{H}_{46 \mathrm{O}}\right)$; (b). Campesterol $\left(\mathrm{C}_{28} \mathrm{H}_{480}\right)$; (c). Stigmasterol $\left(\mathrm{C}_{29} \mathrm{H}_{480} \mathrm{O}\right)$. 


\subsection{Miscellaneous Compounds}

Two alkaloids were isolated from D. altissima [130] and were potent against Phytophthora capsici, a tomato pest. The results were possible but not accurate because of the similarities between $D$. altissima and some amaryllidaceous, as there are still a lack of herbarium data and species. From D. altissima, Eudesmane sesquiterpenoids have been identified. Calcium oxalate needles have been released from D. altissima flowering bulbs [131]. Idioblasts from Drimia have been reported as causative factors of surface irritation [132].

Histamine was not found in Drimia plant. However, calcium oxalate raphides were found in D. maritima, particularly mucilaginous idioblasts. Other compounds such as sinstrin were obtained from $D$. maritima plant, which was utilized for renal clearance. Dihydro-benzofuran-typeneolignan glucoside and free amino acids such as L-azatidine-2carboxilic acid were also isolated from $D$. maritima, together with trace amounts of volatile oils. Approximately $29 \mathrm{kDa}$ glycoprotein, which possessed some antifungal and antitumor effectiveness, was found by gel filtration and reverse-phase HPLC from $D$. indica bulbs. Lectin-like protein and asteroidal sapogenin are other miscellaneous compounds isolated from the bulbs of D. robusta and D. sanguinea, respectively [1]. Medicinal plants produces a variety of bioactive compounds with different concentrations, thus poking important issues in regards to quality, safety and efficacy [133].

\section{Conclusions}

Human populations have depended on the environment since the beginning of time and utilized plants for fuel, clothing, shelter and food, as well as medicine, for their primary survival. This is evident today, as approximately $80 \%$ of the global population relies on plants for their primary health care needs. Historically, knowledge of medicinal plants was verbally transferred from one generation to the next, and limited information was documented. Today, researchers utilize indigenous knowledge to validate the biological properties and toxicity of plants. The current review presented comprehensive information on Drimia species, particularly about the biocompounds producing biological activities and toxicity effects. Drimia is known as a dark-red bulb plant with poisonous characteristics. However, traditional practitioners use its extracts to purify blood and treat sexually transmitted diseases. Various researchers have established that the genus Drimia is used to treat dropsy, respiratory disease, bone and joint complications, skin disorders, epilepsy and cancer due to its numerous secondary biocompounds. The current review clearly shows an increase in biological investigations of Drimia spp. Nevertheless, research has focused on the biological benefits of Drimia; hence, there are limited data on the toxicity of these plants. Because biocompounds from the Drimia genera might have poisonous and healing properties, there is a thin line. In conclusion, there is an existing gap between poisonous and healing properties. Due to the number of fatalities in both humans and animals, we encourage more investigations on the toxicity and safety of these plant species.

Author Contributions: M.C.M., G.S.T., G.T.M., K.P.S., J.F.M. and K.N. were involved in the resources and writing and drafting the original preparation. Conceptualization was performed by M.C.M. and C.N.A. Reviewing and editing were carried out by M.C.M., C.N.A. and J.F. All authors have read and agreed to the published version of the manuscript.

Funding: This research received no external funding.

Institutional Review Board Statement: Not applicable.

Informed Consent Statement: Not applicable.

Data Availability Statement: Not applicable.

Acknowledgments: All authors would like to acknowledge North West University and Walter Sishulu University.

Conflicts of Interest: The authors declare no conflict of interest. 


\section{References}

1. Bozorgi, M.; Amin, G.; Shekarchi, M.; Rahimi, R. Traditional medical uses of Drimia species in terms of phytochemistry, pharmacology and toxicology. J. Tradit. Chin. Med. 2017, 37, 124-139. [CrossRef]

2. Marx, J.; Pretorius, E.; Espag, W.J.; Bester, M.J. Urginea sanguinea: Medicinal wonder or death in disguise? Environ. Toxicol. Pharmacol. 2005, 20, 26-34. [CrossRef]

3. Crespo, M.B.; Martínez-Azorín, M.; Alonso, M.Á. The identity of Drimia purpurascens, with a new nomenclatural and taxonomic approach to the "Drimia undata" group (Hyacinthaceae = Asparagaceae subfam. Scilloideae). Plant Syst. Evol. 2020, 306, 1-18. [CrossRef]

4. Rasethe, M.T. The Utilization and Management of Selected Listed-Threatened or Protected Species in the Limpopo Province, South Africa. Master's Thesis, University of Limpopo, Limpopo, South Africa, 2017.

5. Ndhlala, A.R.; Ncube, B.; Okem, A.; Mulaudzi, R.B.; Van Staden, J. Toxicology of some important medicinal plants in southern Africa. Food Chem. Toxicol. 2013, 62, 609-621. [CrossRef] [PubMed]

6. Watt, J.M.; Breyer-Brandwijk, M.G. The Midicinal and Poisonous Plants of Southern and Easthern Africa, 1962, no. 581.96 W38. Available online: http:/ / www.sidalc.net/cgi-bin/wxis.exe/?IsisScript=UACHBC.xis\&method=post\&formato=2\&cantidad= 1\&expresion $=\mathrm{mfn}=058220$ (accessed on 20 April 2021).

7. Hutchings, A. Zulu Medicinal Plants: An Inventory; University of Natal Press: Pietermaritzburg, South Africa, 1996; p. 464, ISBN 0869808931.

8. Van Wyk, B.E.; Gericke, N. People's Plants: A Guide to Useful Plants of Southern Africa; Briza Publications: Pretoria, South Africa, 2000.

9. Foukaridis, G.N.; Osuch, E.; Mathibe, L.; Tsipa, P. The ethnopharmacology and toxicology of Urginea sanguinea in the Pretoria area. J. Ethnopharmacol. 1995, 49, 77-79. [CrossRef]

10. Moll, E.J.; Strebel, R.C. Poisonous Plants; Struik Publishers: Cape Town, South Africa, 1989.

11. Van Der Bijl, P. Cardiotoxicity of plants in South Africa. Cardiovasc. J. Afr. 2012, 23, 476. [PubMed]

12. Pieter, V.; Pieter, V. Into small pieces, making botanical identification difficult or impossible. Plants known to be toxic contain chemical constituents that can affect a wide range of organ systems; these have been documented in a number of publications. As far as the cardiovascular system. Cardiovasc. J. Afr. 2012, 23, 9.

13. Van Vuuren, S.; Williams, V.L.; Sooka, A.; Burger, A.; Van Der Haar, L. Microbial contamination of traditional medicinal plants sold at the Faraday muthi market, Johannesburg, South Africa. S. Afr. J. Bot. 2014, 94, 95-100. [CrossRef]

14. Moichwanetse, B.I.; Ndhlovu, P.T.; Sedupane, G.; Aremu, A.O. Ethno-veterinary plants used for the treatment of retained placenta and associated diseases in cattle among Dinokana communities, North West Province, South Africa. S. Afr. J. Bot. 2020, 132, 108-116. [CrossRef]

15. Bozorgi, M.; Amin, G.R.; Ostad, S.N.; Samadi, N.; Nazem, E.; Shekarchi, M. Toxicological, chemical and antibacterial evaluation of squill vinegar, a useful product in Persian Traditional Medicine. Res. J. Pharmacogn. 2017, 4, 33-39.

16. Asong, J.A.; Amoo, S.O.; Mcgaw, L.J.; Nkadimeng, S.M.; Aremu, A.O.; Otang-mbeng, W.J.P. Antimicrobial activity, antioxidant potential, cytotoxicity and phytochemical profiling of four plants locally used against skin diseases. Plants 2019, 8, 350. [CrossRef]

17. Pohl, T.; Koorbanally, C.; Crouch, N.R.; Mulholland, D.A. Bufadienolides from Drimia robusta and Urginea altissima (Hyacinthaceae). Phytochemistry 2001, 58, 557-561. [CrossRef]

18. Moodley, N. The Chemical Investigation of the Amaryllidaceae and Hyacinthaceae. Ph.D. Thesis, University of KwaZulu-Natal, Durban, South Africa, 2004.

19. Martinez-Azorin, M.; Crespo, M.B.; Dold, A.P. Trimelopter craibii (Hyacinthaceae, Ornithogaloideae), a new species from the North West Province of South Africa. Phytotaxa 2013, 87, 50-60. [CrossRef]

20. Lekhak, M.M.; Yadav, P.B.; Yadav, S.R. Cytogenetic Studies in Indian Drimia Jacq. (Urgineoideae: Hyacinthaceae). In Chromosome Structure and Aberrations; Springer: New Delhi, India, 2017; pp. 141-165.

21. De Wet, B. Medicinal plants and human health. S. Afr. Pharm. J. 2011, 78, 38-40.

22. Naudé, T.W. The Occurence and Significance of South African Cardiac Glycosides. J. S. Afr. Biol. Soc. 1977, 18, 7-20.

23. Kellerman, T.S.; Coetzer, J.A.W.; Naudé, T.W.; Botha, C.J. Plant Poisonings and Mycotoxicoses of Livestock in Southern Africa, 2nd ed.; Oxford University Press Southern Africa: Cape Town, South Africa, 2005.

24. Majinda, R.R.; Waigh, R.D.; Waterman, P.G. Bufadienolides and other constituents of Urginea sanguinea. Planta Med. 1997, 63, 188-190. [CrossRef]

25. Yadav, P.B.; Lekhak, U.M.; Ghane, S.G.; Lekhak, M.M. Phytochemicals, antioxidants, estimation of cardiac glycoside (Scillaren A) and detection of major metabolites using LC-MS from Drimia species. S. Afr. J. Bot. 2020. [CrossRef]

26. “Drimia maritima". World Checklist of Selected Plant Families. Royal Botanic Gardens, Kew. Available online: https://wcsp. science.kew.org/namedetail.do?name_id=305015 (accessed on 23 April 2021).

27. Jacquin, N.J. "Drimia elata". Collectaneorum Supplementum; Wappler: Vienna, Austria, 1797; pp. 38-39.

28. Evans Pole, I.B. The Flowering Plants of South Africa. Nature 1921, 107, 40.

29. Raimondo, D.; von Staden, L.; Foden, W.; Victor, J.E.; Helme, N.A.; Turner, R.C.; Kamundi, D.A.; Manyama, P.A. Red List of South African Plants; South African National Biodiversity Institute: Pretoria, South Africa, 2009.

30. Manning, J.; Deacon, J.; Goldblatt, P. A review of the Schizobasis group of Drimia Jacq. (Hyacinthaceae: Urgineoideae), and the new species D. sigmoidea from Western Cape, South Africa. S. Afr. J. Bot. 2014, 94, 263-269. [CrossRef]

31. Mabona, U.; Van Vuuren, S.F. Southern African medicinal plants used to treat skin diseases. S. Afr. J. Bot. 2013, 87, 175-193. [CrossRef] 
32. Rabe, T.; Van Staden, J. Antibacterial activity of South African plants used for medicinal purposes. J. Ethnopharmacol. 1997, 56, 81-87. [CrossRef]

33. Maroyi, A. Traditional use of medicinal plants in south-central Zimbabwe: Review and perspectives. J. Ethnobiol. Ethnomed. 2013, 9, 31. [CrossRef]

34. Bhat, P.; Hegde, G.R.; Hegde, G.; Mulgund, G.S. Ethnomedicinal plants to cure skin diseases-An account of the traditional knowledge in the coastal parts of Central Western Ghats, Karnataka. India J. Ethnopharmacol. 2014, 151, 493-502. [CrossRef] [PubMed]

35. Grierson, D.S.; Otang, W.M.; Afolayan, A.J. A Review of the Phytochemistry, Botany, Pharmacology and Toxicology of Arctotis arctotoides (Lf) O. Hoffm. (Asteraceae). Afr. J. Tradit. Complement. Altern. Med. 2014, 11, 118-126. [CrossRef]

36. Masevhe, N.A.; McGaw, L.J.; Eloff, J.N. The traditional use of plants to manage candidiasis and related infections in Venda, South Africa. J. Ethnopharmacol. 2015, 168, 364-372. [CrossRef] [PubMed]

37. Lakshman, A.B.; Paramasivam, G. Biosystematics studies on medicinal plant Urginea indica Kunth. liliaceae-A review. Int. J. Res. Dev. Pharm Life Sci. 2012, 3, 1394-1406.

38. Baskaran, P.; Singh, S.; Van Staden, J. In vitro propagation, proscillaridin A production and antibacterial activity in Drimia robusta Plant Cell Tissue Organ Cult (PCTOC) 2013, 114, 259-267. [CrossRef]

39. Wang, L.; Amin, A.K.; Khanna, P.; Aali, A.; McGregor, A.; Bassett, P.; Gopal Rao, G. An observational cohort study of bacterial co-infection and implications for empirical antibiotic therapy in patients presenting with COVID-19 to hospitals in North West London. J. Antimicrob. Chemother. 2021, 76, 796-803. [CrossRef]

40. Tshitshi, L.; Manganyi, M.C.; Montso, P.K.; Mbewe, M.; Ateba, C.N. Extended Spectrum Beta-Lactamase-Resistant Determinants among Carbapenem-Resistant Enterobacteriaceae from Beef Cattle in the North West Province, South Africa: A Critical Assessment of Their Possible Public Health Implications. Antibiotics 2020, 9, 820. [CrossRef]

41. Kaptchouang Tchatchouang, C.D.; Fri, J.; De Santi, M.; Brandi, G.; Schiavano, G.F.; Amagliani, G.; Ateba, C.N. Listeriosis outbreak in South Africa: A comparative analysis with previously reported cases worldwide. Microorganisms 2020, 8, 135. [CrossRef]

42. Nair, R.; Shah, A.; Baluja, S.; Chanda, S. Synthesis and antibacterial activity of some Schiff base complexes. J. Serbian Chem. Soc. 2006, 71, 733-744. [CrossRef]

43. Chittoor, M.S.; Binny, A.R.; Yadlapalli, S.K.; Cheruku, A.; Dandu, C.; Nimmanapalli, Y. Anthelmintic and antimicrobial studies of Drimia indica (Roxb.) Jessop. bulb aqueous extracts. J. Pharm. Res. 2012, 5, 3677-3686.

44. Pandey, D.; Gupta, A.K. Antimicrobial activity and phytochemical analysis of Urginea indica from Bastar district of Chhattisgarh. Int. J. Pharm. Sci. Rev. Res. 2014, 26, 273-281.

45. Maazoun, A.M.; Hamdane, A.M.; Belhadj, F.; Marzouki, M.N. In vitro antimicrobial activity of Urginea maritima (L.) Baker bulb extract against food-borne pathogens. J. Mater. Environ. Sci. 2019, 10, 1053-1061.

46. Baskaran, P.; Kumari, A.; Van Staden, J. Analysis of the effect of plant growth regulators and organic elicitors on antibacterial activity of Eucomis autumnalis and Drimia robusta ex vitro-grown biomass. Plant Growth Regul. 2018, 85, 143-151. [CrossRef]

47. Pandey, D.; Gupta, A.K. Bioactive Compound in Urginea indica (Kunth.) from Bastar and its Spectral Analysis by HPLC, UV-Vis, FT-IR, NMR, and ESI-MS. SN Compr. Clin. Med. 2019, 1, 241-254. [CrossRef]

48. Shenoy, S.R.; Kameshwari, M.S.; Swaminathan, S.; Gupta, M.N. Major antifungal activity from the bulbs of Indian squill Urginea indica is a chitinase. Biotechnol. Prog. 2006, 22, 631-637. [CrossRef]

49. Matotoka, M.M.; Ndhlala, A.R.; Masoko, P. In vitro inhibition of HIV-1 reverse transcriptase and anti-inflammatory activities of some herbal concoctions sold in the Limpopo Province. S. Afr. J. Bot. 2019, 126, 65-69. [CrossRef]

50. Semenya, S.S.; Potgieter, M.J.; Erasmus, L.J.C. Indigenous plant species used by Bapedi healers to treat sexually transmitted infections: Their distribution, harvesting, conservation and threats. S. Afr. J. Bot. 2013, 87, 66-75. [CrossRef]

51. Kamano, Y.; Satoh, N.; Nakayoshi, H.; Pettit, G.R.; Smith, C.R. Rhinovirus Inhibition by Bufadienolidesl. Chem. Pharm. Bull. 1988, 36, 326-332. [CrossRef]

52. Prabakaran, R.; Joseph, B.; Pradeep, P.N. Phyto medicinal compounds from Urginea indica Kunth: A synthetic drugs potential alternative. J. Pharm. Res. Int. 2016, 1-9. [CrossRef]

53. Belhaddad, O.E.; Charef, N.; Amamra, S.; Zerargui, F.; Baghiani, A.; Khennouf, S.; Arrar, L. Chromatographic fractionation, antioxidant and antibacterial activities of Urginea maritima methanolic extract. Pak. J. Pharm. Sci. 2018, 30, 127-134.

54. Sato, N.; Muro, T. Antiviral activity of scillarenin, a plant bufadienolide. Jpn. J. Microbiol. 1974, 18, 441-448. [CrossRef] [PubMed]

55. Raj, M.S.; Kameshwari, M.S. Extraction, isolation and identification of bioactive compounds in Urginea indica. Plant Cell Biotechnol. Mol. Biol. 2020, 21, 24-29.

56. Shukla, R.; Kumar, A.; Prasad, C.S.; Srivastava, B.; Dubey, N.K. Antimycotic and antiaflatoxigenic potency of Adenocalymma alliaceum Miers. on fungi causing biodeterioration of food commodities and raw herbal drugs. Int. Biodeterior. Biodegrad. 2008, 62, 348-351. [CrossRef]

57. Scogin, R. Anthocyanins of the Bignoniaceae. Biochem. Syst. Ecol. 1980, 8, 273-276. [CrossRef]

58. Otimenyin, S.O. Antiinflammatory Medicinal Plants: A Remedy for Most Disease Conditions? In Natural Products and Drug Discovery; Elsevier: Amsterdam, The Netherlands, 2018; pp. 411-431.

59. Witbooi, H.; Okem, A.; Makunga, N.P.; Kambizi, L. Micropropagation and secondary metabolites in Agathosma betulina (Berg.). S. Afr. J. Bot. 2017, 111, 283-290. [CrossRef]

60. Bakasatae, N.; Kunworarath, N.; Yupanqui, C.T.; Voravuthikunchai, S.P.; Joycharat, N. Bioactive components, antioxidant, and anti-inflammatory activities of the wood of Albizia myriophylla. Braz. J. Pharmacogn. 2018, 28, 444-450. [CrossRef] 
61. Kazemi Rad, H.; Memarzia, A.; Amin, F.; Boskabady, M.H. Relaxant Effect of Urginea maritima on Tracheal Smooth Muscle Mediated by the Effect on Beta-2 Adrenergic, Muscarinic Receptors and Calcium and Potassium Channels. Evid Based Complement. Alternat. Med. 2021, 2021, 1-9. [CrossRef]

62. Alluri, N.; Majumdar, M. In vitro anti-cancer potential and GC-MS analysis of Drimia nagarjunae, an endangered medicinal plant. Bangladesh J. Pharmacol. 2015, 10, 303-307. [CrossRef]

63. Fürst, R.; Zündorf, I.; Dingermann, T. New knowledge about old drugs: The anti-inflammatory properties of cardiac glycosides. Planta Med. 2017, 83, 977-984. [CrossRef] [PubMed]

64. Akhtar, G.; Shabbir, A. Urginea indica attenuated rheumatoid arthritis and inflammatory paw edema in diverse animal models of acute and chronic inflammation. J. Ethnopharmacol. 2019, 238, 111864. [CrossRef] [PubMed]

65. Tahri, Y.; Koubaa, I.; Frikha, D.; Maalej, S.; Allouche, N. Chemical Investigation and Biological Valorization of Two Essential Oils Newly Extracted from Different Parts of Drimia maritima. J. Essent. Oil Bear Plants. 2020, 23, 1022-1034. [CrossRef]

66. Mammadov, R.; Makasçı-Afacan, A.; Uysal-Demir, D.; Görk, Ç. Determination of antioxidant activities of different Urginea maritima (L.) Baker plant extracts. Iran. J. Chem Chem Eng (IJCCE) 2010, 29, 47-53.

67. Mahato, D.; Sahu, A.P.; Sharma, H.P. Phytochemical and antioxidant evaluation of Urginea indica Kunth. Indian J. Tradit Knowdl. 2018, 17, 783-788.

68. Rajput, B.; Golave, A.; Yadav, S.; Jadhav, J.P. Total phenolic concentrations and antioxidant activities in Drimia sp. J. Herbs Spices Med. Plants 2018, 24, 28-36. [CrossRef]

69. Rezzagui, A.; Senator, A.; Benbrinis, S.; Bouriche, H. Free Radical Scavenging Activity, Reducing Power and Anti-Hemolytic Capacity of Algerian Drimia maritima Baker Flower Extracts. J. Drug Deliv. Ther. 2020, 10, 70-78. [CrossRef]

70. Nyambe, M.N.; Beukes, D.R.; Van De Venter, M.; Swanepoel, B.; Hlangothi, B.G. Isolation and characterisation of altissimin: A novel cytotoxic flavonoid C-apioglucoside from Drimia altissima (Asparagaceae). Nat. Prod. Res. 2021, 35, 717-725. [CrossRef]

71. Langat, L.; Langat, M.K.; Wetschnig, W.; Knirsch, W.; Mulholland, D.A. Antiproliferative Bufadienolides from the Bulbs of Drimia altissima. J. Nat. Prod. 2021, 84, 608-661. [CrossRef] [PubMed]

72. Babu Bevara, G.; Naveen Kumar, A.D.; Koteswramma, K.L.; Kumar, B.A.; Kumari, S.; Sastry Yarla, N.; Malla, R.R. C-glycosyl flavone from Urginea indica inhibits growth and dissemination of ehrlich ascites carcinoma cells in mice. Anti Cancer Agent Med. Chem. 2017, 17, 1256-1266. [CrossRef]

73. Winnicka, K.; Bielawski, K.; Bielawska, A.; Miltyk, W. Apoptosis-mediated cytotoxicity of ouabain, digoxin and proscillaridin A in the estrogen independent MDA-MB-231 breast cancer cells. Arch. Pharm. Res. 2007, 30, 1216-1224. [CrossRef] [PubMed]

74. Fouché, G.; Cragg, G.M.; Pillay, P.; Kolesnikova, N.; Maharaj, V.J.; Senabe, J. In vitro anticancer screening of South African plants. J. Ethnopharm. 2008, 119, 455-461. [CrossRef] [PubMed]

75. Saket, K.; Salari, R.; Saburi, E.; Yousefi, M.; Khodadoust, M.A.; Hadi, M.; Afshari, J.T. Anti-cancer effect of Urginea maritima bulb extract invitro through cell cycle arrest and induction of apoptosis in human breast cancer cell lines. Curr. Drug Discov. Technol. 2020. [CrossRef] [PubMed]

76. Hossain, M.S.; Khalequeuzzaman, M.; Hasan, M.N.; Islam, M.A.F.; Rana, M.S. Evaluation of Anticancer Potential Of The Bulbs of Urginea Indica. British J. Med. Health Sci. (BJMHS) 2020, 2, 117-121.

77. Dhar, M.L.; Dhar, M.M.; Dhawan, B.N.; Mehrotra, B.N.; Ray, C. Screening of Indian plants for biological activity: I. Indian J. Exp. Biol. 1968, 6, 232-247.

78. Khare, C.P. Indian Herbal Remedies; Springer: Berlin, Germany, 2004; pp. 464-465.

79. Deepak, A.V.; Salimath, B.P. Antiangiogenic and proapoptotic activity of a novel glycoprotein from $U$. indica is mediated by NF-kB and Caspase activated DNase in ascites tumor model. Biochimie 2006, 88, 297-307. [CrossRef]

80. Cáceres, A.; Menéndez, H.; Méndez, E.; Cohobón, E.; Samayoa, B.E.; Jauregui, E.; Peralta, E.; Carrillo, G. Antigonorrhoeal activity of plants used in Guatemala for the treatment of sexually transmitted diseases. J. Ethnopharmacol. 1995, 48, 85-88. [CrossRef]

81. Shokeen, P.; Bala, M.; Tandon, V. Evaluation of the activity of 16 medicinal plants against Neisseria gonorrhoeae. Int. J. Antimicrob. Agents 2009, 33, 86-91. [CrossRef] [PubMed]

82. Thatoi, H.N.; Panda, S.K.; Rath, S.K.; Dutta, S.K. Antimicrobial activity and ethnomedicinal uses of some medicinal plants from Similipal Biosphere Reserve, Orissa. Asian J. Plant. Sci. 2008, 7, 260-267. [CrossRef]

83. Lobo, V.; Patil, A.; Phatak, A.; Chandra, N. Free radicals, antioxidants and functional foods: Impact on human health. Pharm Rev. 2010, 4, 118-126. [CrossRef]

84. Soni, L.K.; Jain, S.K.; Dobhal, S.; Parasher, P.; Dobhal, M.P. Free radical scavenging activity of Urginea indica, Alhagi maurorum, Crinum asiaticum and Prosopis cineraria. Int. J. Pharm. Phytochem. Res. 2015, 7, 311-314.

85. Gupta, A.; Singh, S.K.; Yadav, A.K. Pharmacological evaluation of antidiabetic activity of Urginea indica in laboratory animals. Int. J. Nutr. Pharm. Neurol. Dis. 2015, 5, 63-68.

86. Rahman, M.M.; Chowdhury, J.A.; Habib, R.; Saha, B.K.; Salauddin, A.D.M.; Islam, M.K. Anti-inflammatory, anti-arthritic and analgesic activity of the alcoholic extract of the plant Urginea indica kunth. Int. J. Pharm. Sci. Res. 2011, 2, $2320-2324$.

87. Ngugi, G.W.; Jager, A.K.; Van Staden, J. In vitro propagation of Drimia robusta. Bak. S. Afr. J. Bot. 1998, 64, 266-268. [CrossRef]

88. Hammouda, F.M.; Ismail, S.I.; Abdel-Azim, N.S.; Shams, K.A. Urginea maritima (L.) Baker Liliaceae. Baker. J. Linn. London (Bot.) 1873, 13, 221.

89. Ncube, B.; Finnie, J.F.; Van Staden, J. Seasonal variation in antimicrobial and phytochemical properties of frequently used medicinal bulbous plants from South Africa. S. Afr. J. Bot. 2011, 77, 387-396. [CrossRef] 
90. Sathiyamoorthy, P.; Lugasi-Evgi, H.; Schlesinger, P.; Kedar, I.; Gopas, J.; Pollack, Y.; Golan-Goldhirsh, A. Screening for cytotoxic and antimalarial activities in desert plants of the negev and bedouin market plant products. Pharm. Biol. 1999, 37, 188-195. [CrossRef]

91. Nejatbakhsh, F.; Karegar-Borzi, H.; Amin, G.; Eslaminejad, A.; Hosseini, M.; Bozorgi, M.; Gharabaghi, M.A. Squill Oxymel, a traditional formulation from Drimia maritima (L.) Stearn, as an add-on treatment in patients with moderate to severe persistent asthma: A pilot, triple-blind, randomized clinical trial. J. Ethnopharmacol. 2017, 196, 186-192. [CrossRef] [PubMed]

92. Bayazit, V.; Konar, V. Analgesic effects of scilliroside, proscillaridin-a and taxifolin from squill bulb (Urginea maritima) on pains. Digest. J. Nanomater. Biostruct. 2010, 5, 465-467.

93. El-Seedi, H.R.; Burman, R.; Mansour, A.; Turki, Z.; Boulos, L.; Gullbo, J.; Goransson, U. The traditional medical uses and cytotoxic activities of sixty-one Egyptian plants: Discovery of an active cardiac glycoside from Urginea maritima. J. Ethnopharmacol. 2013, 145, 746-757. [CrossRef] [PubMed]

94. Luyt, R.P.; Jäger, A.K.; Van Staden, J. The rational usage of Drimia robusta Bak. in traditional medicine. S. Afr. J. Bot. 1999, 65, 291-294. [CrossRef]

95. Moodley, N.; Crouch, N.R.; Mulholland, D.A. Bufadienolides from Drimia macrocentra and Urginea riparia (Hyacinthaceae: Urgineoideae). Phytochemistry 2007, 68, 2415-2419. [CrossRef] [PubMed]

96. Rhimi, W.; Camarda, A.; Saidi, M.; Boulila, A.; Otranto, D.; Cafarchia, C. Chemical characterization and acaricidal activity of Drimia maritima (L) bulbs and Dittrichia viscosa leaves against Dermanyssus gallinae. Vet. Parasitol. 2019, 268, 61-66. [CrossRef] [PubMed]

97. Kakouri, E.; Kanakis, C.; Trigas, P.; Tarantilis, P.A. Characterization of the chemical composition of Drimia numidica plant parts using high-resolution mass spectrometry: Study of their total phenolic content and antioxidant activity. Anal. Bioanal. Chem. 2019, 411, 3135-3150. [CrossRef] [PubMed]

98. Karimi, F.; Babazadeh, R.; Jouya, S.; Zojaji, A. Squill oil for decreasing dyspareunia and increasing sexual satisfaction in menopausal women: A triple-blind randomized controlled trial. Avicenna J. Phytomed. 2021, 11, 464-472. [CrossRef]

99. Botha, C.J.; Venter, E. Drimia Species. Available online: http://hdl.handle.net/2263/8474 (accessed on 27 May 2021).

100. Knittel, D.N.; Lorenz, P.; Huber, U.; Stintzing, F.C.; Kammerer, D.R. Characterization of the cardiac glycoside and lipid profiles of Strophanthus kombé Oliv. seeds. Z. Naturforsch. 2016, 71, 55-64. [CrossRef]

101. Aswal, S.; Kumar, A.; Semwal, R.B.; Chauhan, A.; Kumar, A.; Lehmann, J.; Semwal, D.K. Drimia indica: A plant used in traditional medicine and its potential for clinical uses. Medicina 2019, 55, 255. [CrossRef]

102. Botha, C.J.; Penrith, M.L. Poisonous plants of veterinary and human importance in southern Africa. J. Ethnopharmacol. 2008, 119, 549-558. [CrossRef]

103. Louw, P.G.J. Transvaalin, a cardiac glycoside isolated from Urginea burkei, BKR. (Transvaal slangkop). Onderstepoort J. Vet. Res. 1952, 25, 123-131.

104. Brooks, J.E.; Htun, P.T. Laboratory evaluation of scilliroside used as a rodenticide against the lesser bandicoot rat, Bandicota bengalensis. Epidemiol. Infect. 1980, 85, 227-234. [CrossRef]

105. Teshome, M.; Kassa, H.; Charles, K. The toxicity of plant material, Drimia altissima (Urginea altissima), against the field rat, Arvicanthis abyssinicus: A potential non-synthetic rodenticide. Ethiop. J. Health Dev. 2010, 24, 175-179. [CrossRef]

106. Saadane, F.Z.; Habbachi, W.; Habbachi, S.; Boublata, N.E.I.; Slimani, A.; Tahraoui, A. Toxic effects of Drimia maritima (Asparagaceae) ethanolic extracts on the mortality, development, sexual behaviour and oviposition behaviour of Drosophila melanogaster (Diptera: Drosophilidae). J. Anim. Behav. Biometeorol. 2020, 9, 2102. [CrossRef]

107. Tuncok, Y.; Kozan, O.; Cavdar, C.; Guven, H.; Fowler, J. Urginea maritima (squill) toxicity. J. Toxicol. Clin. Toxicol. 1995, 33, 83-86. [CrossRef]

108. Smith, W.; Gould, B.A.; Marshall, A.J. Wenckebach's phenomenon induced by cough linctus. Br. Med. J. 1986, 292, 868. [CrossRef]

109. Polat, M.; Oztas, P.; Yalcin, B.; Artuz, F.; Lenk, N.; Alli, N. Contact dermatitis as a result of Urginea maritima. Contact Dermat. 2007, 57, 343-344. [CrossRef]

110. Badalamenti, N.; Rosselli, S.; Zito, P.; Bruno, M. Phytochemical profile and insecticidal activity of Drimia pancration (Asparagaceae) against adults of Stegobium paniceum (Anobiidae). Nat. Prod. Res. 2020, 3, 1-11. [CrossRef] [PubMed]

111. Hamouda, A.B.; Chaieb, I.; Zouari, L.; Zarrad, K.; Laarif, A. Toxicological effects of Urginea maritima (L.) against the red flour beetle (Coleoptera: Tenebrionidae). J. Entomol Zool Stud. 2015, 4, 17-20.

112. Knittel, D.N.; Stintzing, F.C.; Kammerer, D.R. Metabolic fate of cardiac glycosides and flavonoids upon fermentation of aqueous sea squill (Drimia maritima L.) extracts. J. Pharm. Biomed. Anal. 2015, 110, 100-109. [CrossRef] [PubMed]

113. Sharma, H.J.; Devi, N.S. Phytochemical Analysis of Drimia Species. Int J. Appl. Sci. Res. Rev. 2017, 4, 12.

114. Stoll, A.; Suter, E.; Kreis, W.; Bussemaker, B.; Hofmann, A. Die herzaktiven substanzen der meerzwiebel. Scillaren A Helv. Chim. Acta 1933, 16, 703-733. [CrossRef]

115. Bartnik, M.; Facey, P.C. Glycosides. In Pharmacognosy; Academic Press: Cambridge, MA, USA, 2017; pp. $101-161$.

116. Prassas, I.; Diamandis, E.P. Novel therapeutic applications of cardiac glycosides. Nat. Rev. Drug Dis. 2008, 7, 926-935. [CrossRef] [PubMed]

117. Patel, S. Plant-derived cardiac glycosides: Role in heart ailments and cancer management. Biomed. Pharmacother. 2016, 84, 1036-1041. [CrossRef] [PubMed]

118. Calderón-Montaño, J.M.; Burgos-Morón, E.; Orta, M.L.; Maldonado-Navas, D.; García-Domínguez, I.; López-Lázaro, M. Evaluating the cancer therapeutic potential of cardiac glycosides. Nat. Bioact. Cancer Treat. Prev. 2014, 2014, 794930. [CrossRef] [PubMed] 
119. Mijatovic, T.; Dufrasne, F.; Kiss, R. Cardiotonic steroids-mediated targeting of the Na+/K+-ATPase to combat chemoresistant cancers. Curr. Med. Chem. 2012, 19, 627-646. [CrossRef]

120. Challinor, V.L.; De Voss, J.J. Open-chain steroidal glycosides, a diverse class of plant saponins. Nat. Prod. Rep. 2013, 30, 429-454. [CrossRef] [PubMed]

121. Morsy, N. Cardiac glycosides in medicinal plants. In Aromatic and Medicinal Plants—Back to Nature; El-Shemy, H., Ed.; IntechOpen: London, UK, 2017.

122. He, Y.; Khan, M.; Yang, J.; Yao, M.; Yu, S.; Gao, H. Proscillaridin A induces apoptosis, inhibits STAT3 activation and augments doxorubicin toxicity in prostate cancer cells. Inter. J. Med. Sci. 2018, 15, 832. [CrossRef]

123. Iizuka, M.; Warashina, T.; Noro, T. Bufadienolides and a new lignan from the bulbs of Urginea maritima. Chem. Pharm. Bull. 2001, 49, 282-286. [CrossRef] [PubMed]

124. Karaś, K.; Sałkowska, A.; Dastych, J.; Bachorz, R.A.; Ratajewski, M. Cardiac glycosides with target at direct and indirect interactions with nuclear receptors. Biomed. Pharmacother. 2020, 127, 110106. [CrossRef] [PubMed]

125. Liang, X.M.; Jin, Y.; Wang, Y.P.; Jin, G.W.; Fu, Q.; Xiao, Y.S. Qualitative and quantitative analysis in quality control of traditional Chinese medicines. J. Chromatogr. A 2009, 1216, 2033-2044. [CrossRef]

126. Knittel, D.N.; Kammerer, D.R.; Stintzing, F.C. Characterization of phenolic compounds and cardiac glycosides from red sea squill (Urginea maritima (L.) Baker) by RP-HPLC-DAD-MSn. Planta Med. 2013, 79, 13. [CrossRef]

127. Sultana, N.; Akter, K.; Nahar, N.; Khan, M.S.H.; Mosihuzzaman, M.; Sohrab, M.H.; Krohn, K. Novel flavonoid glycosides from the bulbs of Urginea indica Kunth. Nat. Prod. Res. 2010, 24, 1018-1026. [CrossRef] [PubMed]

128. Rishi, A.; Sneha, S. Quantitative estimation of-sitosterol and stigmasterol in Gloriosa superba L. and Urginea indica (Roxb.) Kunth. J. Med. Plants Res. 2013, 7, 3127-3130.

129. Fernandes, P.; Cabral, J.M.S. Phytosterols: Applications and recovery methods. Biores. Technol. 2007, 98, 2335-2350. [CrossRef]

130. Mulholland, D.A.; Schwikkard, S.L.; Crouch, N.R. The chemistry and biological activity of the Hyacinthaceae. Nat. Prod Rep. 2013, 30, 1165-1210. [CrossRef]

131. Kim, H.M.; Lee, J.S.; Sezirahiga, J.; Kwon, J.; Jeong, M.; Lee, D.; Choi, J.H.; Jang, D.S. A new canthinone-type alkaloid isolated from Ailanthus altissima Swingle. Molecules 2016, 21, 642. [CrossRef] [PubMed]

132. Nakata, P.A. Advances in our understanding of calcium oxalate crystal formation and function in plants. Plant Sci. 2003, 164, 901-909. [CrossRef]

133. Jamshidi-Kia, F.; Lorigooini, Z.; Amini-Khoei, H. Medicinal plants: Past history and future perspective. J. Herb. Med. Pharmacol. 2018, 7, 1-7. [CrossRef] 